Мальцев Дмитро Валерійович, кандидат медичних наук, завідувач лабораторії імунології та молекулярної біології НДІ ЕКМ НМУ імені О. О. Богомольця; 01601, бульвар Шевченка 13, м. Київ, Україна; dmaltsev@ukr.net; +38 (068) 100-85-95.

ORCID https://orcid.org/0000-0002-6615-3072

\title{
ПРОБЛЕМА РАССТРОЙСТВ СПЕКТРА АУТИЗМА, АССОЦИИРОВАННЫХ С ГЕНЕТИЧЕСКИМ ДЕФИЦИТОМ ФОЛАТНОГО ЦИКЛА, КАК ПРОЯВЛЕНИЯ ИММУНОДЕФИЦИТНОЙ БОЛЕЗНИ
}

\begin{abstract}
Анотація
Мальцев Д. В., кандидат медичних наук, завідувач лабораторії імунології та молекулярної біології НДІ ЕКМ НМУ імені О. О. Богомольця; м. Київ, Україна. Проблема розладів спектру аутизму, асоційованих 3 генетичним дефіцитом фолатного циклу, як прояву імунодефіцитної хвороби

Ключові слова: аутизм, фолатний цикл, NK-, NKT-клітини, імунодефіцит.

Постановка проблеми. Останнім часом все більше дослідників вказують на зв’язок розладів аутистичного спектру, асоційованих 3 первинним фолатним дефіцитом, з імунозалежною патологією.

Аналіз останніх досліджень і публікацій. У джерелах наукової літератури описані різні форми первинних імунодефіцитів при розладах аутистичного спектру, а дослідження, присвячені деяким первинним імунним дисфункціям, вказують на підвищений ризик розвитку аутизму.

Формулювання мети: провести комплексну оцінку імунного статусу у дітей 3 розладами аутистичного спектру, асоційованими 3 генетично детермінованим дефіцитом фолатного циклу.
\end{abstract}


Виклад основного матеріалу. В результаті оцінки імунного статусу встановлено, що майже всі діти з генетичним дефіцитом фолатного циклу були імуноскомпрометованими особами. Основою виявленого імунодефіциту було різко знижене кількість клітин субпопуляцій лімфоцитів 3 фенотипом CD3-CD16 + CD56 +, що отримали назву природних кілерів (natural killers, NK), і фенотипом CD3 + CD16 + CD56 +, або природних кілерних Т-клітин (natural killer T-cell, NKT) в периферичній крові. Крім цього, набагато рідше серед дітей з аутистичним спектром відзначалися інші порушення імунного статусу: зниження кількості CD8 + Т-лімфоцитів (23\%), CD4 + Т-клітин (12\%), CD19 + В-лімфоцитів (9\% випадків). Дісімуноглобулінемія, що включає ізольовані і комбіновані дефіцити окремих класів і субкласів імуноглобулінів, виявлена в $43 \%$ випадків, однак найчастіше була неглибокою i носила транзиторний характер. Гіпоімуноглобулінемія зареєстрована лише в 17\% випадків. Дефіцит мієлопероксидази фагоцитів відзначався в 35\% випадків і комбінувався з порушеннями в інших ланках імунітету у варіабельній манері. Оскільки в структурі імунодефіциту у дітей з розладами спектру аутизму переважали клітинні порушення імунітету, наявний інфекційний синдром був представлений переважно внутрішньоклітинними патогенами, перш за все - опортуністичними вірусами 3 сімейства герпесу. Відзначалася підвищена продукція антимозкових антитіл, переважно - проти основного білка мієліну та нейронспецифічної енолази (близько 70\%), а також ознаки аутосенсибілизації нейтрофілів (32\%) і CD8 + цитотоксичних Т-лімфоцитів (24\% випадків) до антигенів мозку. Ознаки антимієлінового аутоімунітету корелювали з радіологічними проявами лейкоенцефалопатії. Серед проявів антинейронального аутоімунітету найчастіше виявлялася продукція аутоантитіл до глутамінової декарбоксилази нейронів (GADA) - в 61\% випадків, рідше - до калієвих каналів нервових клітин (34\% випадків). У деяких пацієнтів мала місце аутоімунізація до амфіфізіну (19\%) і рецепторів до N-метил-D-аспартату (NMDA) (3\%). 
Висновки і перспективи подальших досліджень. Імунна дисфункція при розладах спектра аутизму має варіабельний імунологічний фенотип, однак дефіцити NK-, NKT-клітин, CD8 + T-лімфоцитів і мієлопероксидази $\epsilon$ найбільш типовими ознаками хвороби. Найімовірніше, це нова форма первинного імунодефіциту, що потребує подальшого вивчення.

\section{Аннотация}

Мальщев Д. В., кандидат медицинских наук, заведующий лабораторией иммунологии и молекулярной биологии НИИ ЭКМ НМУ имени А. А. Богомольца; г. Киев, Украина. Проблема расстройств спектра аутизма, ассоциированных с генетическим дефицитом фолатного цикла, как проявления иммунодефицитной болезни.

Ключевые слова: аутизм, фолатный цикл, NK-, NKT-клетки, иммунодефицит.

Постановка проблемы. В последнее время все больше исследователей указывают на связь расстройств аутистического спектра, ассоциированных с первичным фолатным дефицитом, с иммунозависимой патологией.

Анализ последних исследований и публикаций. В источниках научной литературы описаны различные формы первичных иммунодефицитов при расстройствах аутистического спектра, а исследования, посвященные некоторым первичным иммунным дисфункциям, указывают на повышенный риск развития аутизма.

Формулировка цели: провести комплексную оценку иммунного статуса у детей с расстройствами аутистического спектра, ассоциированными с генетически детерминированным дефицитом фолатного цикла.

Изложение основного материала. В результате оценки иммунного статуса установлено, что почти все дети с генетическим дефицитом фолатного цикла были иммуноскомпрометированными лицами. Основой выявленного иммунодефицита было резко сниженное количество клеток субпопуляций лимфоцитов с фенотипом CD3-CD16+CD56+, получившие 
название естественных киллеров (natural killers, NK), и фенотипом CD3+CD16+CD56+, или естественных киллерных Т-клеток (natural killer Tcell, NKT) в периферической крови. Помимо этого, гораздо реже среди детей с аутистическим спектром отмечались другие нарушения иммунного статуса: снижение количества CD8+ Т-лимфоцитов (23\%), CD4+ Т-клеток (12\%), CD19+ В-лимфоцитов (9\% случаев). Дисиммуноглобулинемия, включающая изолированные и комбинированные дефициты отдельных классов и субклассов иммуноглобулинов, выявлена в 43\% случаев, однако была неглубокой и носила транзиторный характер. Гипоиммуноглобулинемия зарегистрирована в 17\% случаев. Дефицит миелопероксидазы фагоцитов отмечался в 35\% случаев и комбинировался с нарушениями в других звеньях иммунитета в вариабельной манере. Поскольку в структуре иммунодефицита у детей с расстройствами спектра аутизма преобладали клеточные нарушения иммунитета, имеющийся инфекционный синдром был представлен преимушественно внутриклеточными патогенами, прежде всего - оппортунистическими вирусами из семейства герпеса. Отмечалась повышенная продукция антимозговых антител, преимущественно - против основного белка миелина и нейронспецифической энолазы (около 70\%), а также признаки аутосенсибилизации нейтрофилов (32\%) и CD8+ цитотоксических Т-лимфоцитов (24\% случаев) к антигенам мозга. Признаки антимиелинового аутоиммунитета коррелировали с радиологическими проявлениями лейкоэнцефалопатии. Среди проявлений антинейронанального аутоиммунитета чаще всего выявлялась продукция аутоантител к глутаминовой декарбоксилазе нейронов (GADA) - в 61\% случаев, реже - к калиевым каналам нервных клеток (34\% случаев). У некоторых пациентов имела место аутоиммунизация к амфифизину (19\%) и рецепторам к N-метилD-аспартату (NMDA) (3\%).

Выводы и перспективы дальнейших исследований. Иммунная дисфункция при расстройствах спектра аутизма имеет вариабельный иммунологический фенотип, однако дефициты NK-, NKT-клеток, CD8+ T- 
лимфоцитов и миелопероксидазы являются наиболее типичными признаками болезни. По-видимому, это новая форма первичного иммунодефицита, требующая дальнейшего изучения.

\section{Annotation}

Maltsev D. V., Ph.D., Head of Laboratory of Immunology and Molecular Biology, Scientific-Research Institute of Experimental and Clinical Medicine at the O. Bogomolets NMU; Kyiv, Ukraine. The problem of autism spectrum disorders associated with the genetic deficiency of the folate cycle as a manifestation of the immunodeficiency disease.

Key words: autism, folate cycle, NK-, NKT-cells, immunodeficiency.

Formulation of the problem. Recently, more researchers have pointed out the association of autistic spectrum disorders, associated with primary folate deficiency, with immune-related pathology.

Analysis of recent research and publications. The sources of scientific literature describe various forms of primary immunodeficiency disorders in autistic spectrum disorders, and studies on some primary immune dysfunctions indicate an increased risk of developing autism.

Target formulation: To conduct a comprehensive assessment of the immune status in children with autism spectrum disorders associated with a genetically determined folate cycle deficiency.

The presentation of the main material. As a result of assessing the immune status, it was found that almost all children with a genetic deficiency in the folate cycle were immunocompromised individuals. The basis of the identified immunodeficiency was a sharply reduced number of cells of lymphocyte subpopulations with the phenotype CD3 - CD16 + CD56 +, called natural killers (natural killers, NK), and the phenotype CD3 + CD16 + CD56 +, or natural killer T cells (natural killer T-cell, NKT) in peripheral blood. In addition, other disorders of the immune status were much less common among children with autistic spectrum: a decrease in the number of CD8 + T-lymphocytes (23\%), CD4 + T-cells (12\%), 
CD19 + B-lymphocytes (9\% of cases). Disimmunoglobulinemia, including isolated and combined deficiencies of classes and subclasses of immunoglobulins, was detected in $43 \%$ of cases, but more often it was shallow and was transient in nature. Hypoimmunoglobulinemia is registered only in $17 \%$ of cases. Phagocytic myeloperoxidase deficiency was noted in $35 \%$ of cases and was combined with disturbances in other parts of the immune system in a variable manner. Since the immune deficiency in children with autism spectrum disorders was dominated by cellular immunity disorders, the existing infectious syndrome was represented mainly by intracellular pathogens, the majority - opportunistic viruses from. family herpes. There was an increased production of anti-brain antibodies, mainly against the myelin basic protein and neuron-specific enolase (about 70\%), as well as signs of autosensitization of neutrophils (32\%) and CD8 + cytotoxic T-lymphocytes ( $24 \%$ of cases) to brain antigens. Signs of anti-myelin autoimmunity correlated with radiological manifestations of leukoencephalopathy. Among the manifestations of anti-neuronal autoimmunity, the production of autoantibodies to glutamine decarboxylase neurons (GADA) was most often detected - in $61 \%$ of cases, less often - to potassium channels of nerve cells (34\% of cases). Some patients had autoimmunization to amphiphysin (19\%) and receptors for N-methylD-aspartate (NMDA) (3\%).

Conclusions and prospects for further research. Immune dysfunction in autism spectrum disorders has a variable immunological phenotype, however, deficiencies of NK-, NKT-cells, CD8 + T-lymphocytes and myeloperoxidase are the most typical signs of the disease. Apparently, this is a new form of primary immunodeficiency, requiring further study.

Ключевые слова: аутизм, фолатный цикл, NK-, NKT-клетки, иммунодефицит.

Постановка проблемы. Расстройства психики аутистического спектра являются актуальной проблемой психиатрии, которая до сих пор не нашла 
своего решения. В последнее время все больше исследователей указывают на связь расстройств аутистического спектра, ассоциированных с первичным фолатным дефицитом, с иммунозависимой патологией.

Анализ последних исследований и публикаций. В источниках научной литературы описаны различные формы первичных иммунодефицитов при расстройствах аутистического спектра, а исследования, посвященные некоторым первичным иммунным дисфункциям, указывают на повышенный риск развития аутизма; также продемонстрирована связь проявлений аутизма с некоторыми локусами гистосовместимости, подобно ряду аутоиммунных и аллергических синдромов $[13,14]$. Имеются неединичные сообщения о появлении аутизма у взрослых и детей после перенесенных эпизодов нейроинфекций, преимущественно - оппортунистического спектра [3, 4]. Более того, результаты ряда клинических испытаний указывают на пользу от применения иммунотерапии у пациентов с расстройствами аутистического спектра [2]. Описаны различные формы иммунодефицитов неуточненного происхождения у детей с аутистическим спектром. Так, Santaella M.L. с соавт. показали, що избирательный дефицит IgA встречается среди пациентов с расстройствами аутистического спектра в 10,3\%, тогда как в контрольной группе здоровых детей - лишь в 1,6 \% случав [12]. Russo A.J. с соавт. продемонстрировали тесную связь между расстройствами аутистического спектра и дефицитом миелопероксидазы нейтрофилов [11]. Reinert P. с соавт. описали 20 случаев коревого подострого склерозирующего энцефалита с прогрессирующими психическими нарушениями у пациентов с избирательным клеточным дефицитом к вирусу кори [10]. Jyonouchi Н. с соавт. показали ассоциацию расстройств аутистического спектра у детей с избирательным дефицитом специфических антиполисахаридных антител и дисфункцией моноцитов [6]. Известна также ассоциация PANDAS и синдрома Туретта с избирательным дефицитом IgA [7], а рефрактерных эпилепсий у детей - с дефицитами субклассов IgG [9]. Все эти весомые 
аргументы заставляют обратить более пристальное внимание на роль иммунозависимых механизмов в патогенезе аутистических психических нарушений.

Формулировка цели: провести комплексную оценку иммунного статуса у детей с расстройствами аутистического спектра, ассоциированными с генетически детерминированным дефицитом фолатного цикла.

Изложение основного материала. В проспективном контролируемом одноцентровом исследовании, проводившемся нами с 2010 по 2015 гг, принимали участие 78 детей с диагнозом расстройств психики аутистического спектра и/или детского церебрального паралича. Это были пациенты из различных регионов Украины в возрасте от 2 до 10 лет, 47 мальчиков и 31 девочка. Контрольную группу составили 34 здоровых ребенка с похожим возрастным и гендерным распределением. Все пациентам проводилось комплексное иммунологическое обследование в Институте иммунологии и аллергологии НМУ имени А.А. Богомольца, которое помимо общего анализа крови, включало изучение субпопуляционного состава лимфоцитов с использованием лазерной проточной цитофлуориметрии (цитофлуориметр Epics X1, США) и метода непрямой иммунофлуоресценции с моноклональными антителами к CD-маркерам с двумя или тремя метками $(\mathrm{CD} 3+, \quad \mathrm{CD} 3+\mathrm{CD} 4+, \quad \mathrm{CD} 3+\mathrm{CD} 8+, \quad \mathrm{CD} 3-\mathrm{CD} 19+, \quad \mathrm{CD} 3-\mathrm{CD} 16+\mathrm{CD} 56+$ CD3+CD16+CD56+) (реактивы Beckman Coulter, США). Фагоцитоз оценивали по данным латекс-теста с определением показателя фагоцитоза, фагоцитарного индекса, количества активных фагоцитов и фагоцитарной ёмкости крови, а также по активности ферментов миелопероксидазы (цитофлуориметрия) и концентрации иммуноглобулинов основных классов (M, G, A) устанавливали по результатам простой радиальной иммунодиффузии по Манчини. Концентрацию классов IgE, IgD и субклассов IgG (IgG1, IgG2, IgG3, IgG4) в сыворотке крови измеряли при помощи твердофазного иммуноферментного анализа (ВекторБЕСТ, РФ). Оценивали также сывороточные концентрации 
известных биомаркеров генетического дефицита фолатного цикла гомоцистеина, фолиевой кислоты, витаминов В12 и В6. Все дети проходили МРТ головного мозга в конвенционных режимах (Т1- и Т2-взвешенный, FLAIR) на томографах с величиной магнитной индукции не менее 1,5 Тл.

Статистический анализ полученной информации обработан методами структурного и сравнительного анализов при помощи электронной программы Microsoft Excel. C целью установления достоверности отличий результатов применяли Т-критерий Стьюдента с расчетом коэффициента доверительной вероятности р (параметрический критерий) и число знаков Z по Урбаху (непараметрический критерий). Для изучения связи между полиморфизмами генов фолатного цикла и показателями иммунного статуса использовали критерий хи-квадрат $\left(\chi^{2}\right)$ Пирсона, сравнивая полученное значение с табличным при заданном числе степеней свободы и уровнях достоверности $\mathrm{p}=0,05$ и $\mathrm{p}=0,01$. При фактических значениях от 5 до 9 применяли дополнительно поправку Йейтса, а при менее 5 - точный тест Фишера.

В результате оценки иммунного статуса установлено, что почти все дети с генетическим дефицитом фолатного цикла были иммуноскомпрометированными лицами, причем отмечались некоторые однотипные нарушения иммунитета. Основой выявленного иммунодефицита было резко сниженное количество клеток субпопуляций лимфоцитов с фенотипом CD3-CD16+CD56+, получившие название естественных киллеров (natural killers, NK), и фенотипом CD3+CD16+CD56+, или естественных киллерных Т-клеток (natural killer T-cell, NKT) в периферической крови. Эти миноритарные субпопуляции крайне важны в осуществлении противовирусного и антиопухолевого иммунитета, что в значительной мере может объяснить избирательное нарушение противовирусной резистентности у детей исследуемой группы, равно как и повышенную склонность к развитию неоплазий, причем преимущественно - вирус-индуцированных форм онкологической патологии, у пациентов с первичным дефицитом 
ферментов фолатного цикла. Помимо этого, дефицит NK- и NKT-клеток ассоциирован с повышенной склонностью к развитию аутоиммунных осложнений [5] и гиперчувствительности замедленного типа [13], что согласуется с неоднократно зафиксированным феноменом аномально повышенной продукции аутоантител к мозговым антигенам и непереносимости многих пищевых аллергенов у детей с аутистическим спектром. Дефицит NK- и NKT-клеток также объясняет частое развитие побочных эффектов после вакцинаций, особенно - при введении живой аттенуированной вакцины против кори, краснухи и эпидемического паротита. Указанная форма клеточного иммунодефицита отмечалась среди участников исследуемой группы в 91\% случаев, т.е. являлась специфическим признаком, в то время как среди здоровых детей контрольной группы признаки аналогичного иммунологического фенотипа имели место лишь в 27\% случаев, причем обычно отмечалось незначительное снижение количества клеток $\left(\mathrm{p}<0,05 ; \mathrm{Z}<\mathrm{Z}_{0,05}\right)$.

Помимо этого, гораздо реже среди детей с аутистическим спектром отмечались другие нарушения иммунного статуса: снижение количества CD8+ Т-лимфоцитов (23\%), CD4+ T-клеток (12\%), CD19+ В-лимфоцитов (9\% случаев). Таким образом, только в $23 \%$ случаев был тотальный дефицит всех основных противовирусных субпопуляций лимфоцитов: Т-киллеров, естественных киллеров и естественных киллерных Т-лимфоцитов, причем именно у таких детей отмечалась наибольшая вирусная нагрузка на момент вступления в исследование. Преимущественно имел место избирательный дефицит противовирусных клеток врожденного иммунитета, а количество CD8+ T-лимфоцитов нередко оказывалось компенсаторно повышенным, что способствовало некоторому уменьшению вирусной нагрузки на организм ребенка. Такую форму иммунодефицита можно было легко идентифицировать в общем анализе крови, зафиксировав аномально малое количество клеток с фенотипом больших гранулярных лимфоцитов. Только у каждого десятого участника исследуемой группы было тотальное снижение 
всех исследуемых субпопуляций лимфоцитов, что отражалось в виде лимфопении в общем анализе крови. Нарушения отмечались и в гуморальном звене иммунитета. Дисиммуноглобулинемия, включающая изолированные и комбинированные дефициты отдельных классов и субклассов иммуноглобулинов, выявлена в 43\% случаев, однако чаще всего была неглубокой и носила транзиторный характер. Гипоиммуноглобулинемия зарегистрирована лишь в 17\% случаев. Дефицит миелопероксидазы фагоцитов отмечался в 35\% случаев и комбинировался с нарушениями в других звеньях иммунитета в вариабельной манере.

Изолированный дефицит клеток-киллеров имел место в 19\% случаев, так как более чем у половины участников исследуемой группы отмечался расширенный иммунологический фенотип (54\%), при котором наряду с выраженным и стойким дефицитом NK- и NKT-клеток отмечались менее глубокие и преимущественно транзиторные нарушения в других звеньях иммунитета, а именно - дефицит CD8+ Т-лимфоцитов, различные виды дисиммуноглобулинемии и дефицит миелопероксидазы фагоцитов (табл. 1, 2).

Таблица 1.

Сравнительный анализ средних величин показателей иммунного статуса у пациентов групп наблюдения

\begin{tabular}{|c|c|c|c|}
\hline Клетка/фактор & Х ИГ & $\mathbf{X} \mathbf{K} \boldsymbol{\Gamma}$ & $\begin{array}{c}\text { Статистическая } \\
\text { значимость } \\
\end{array}$ \\
\hline NK, х109/л & $0,09 \pm 0,002$ & $0,22 \pm 0,2$ & $\mathrm{p}<0,05 ; \mathrm{Z}<\mathrm{Z}_{0,05}$ \\
\hline $\mathrm{NKT}, \mathrm{x} 10^{9} / л$ & $0,02 \pm 0,003$ & $0,17 \pm 0,4$ & $\mathrm{p}<0,05 ; \mathrm{Z}<\mathrm{Z}_{0,05}$ \\
\hline CD8+ Т-лимфоциты, х109/л & $0,71 \pm 0,2$ & $0,94 \pm 0,2$ & $\mathrm{p}>0,05 ; \mathrm{Z}>\mathrm{Z}_{0,05}$ \\
\hline CD4+ Т-лимфоциты, х109/л & $3,99 \pm 1,1$ & $3,24 \pm 1,7$ & $\mathrm{p}>0,05 ; Z>Z_{0,05}$ \\
\hline CD19+ В-лимфоциты, х109/л & $0,48 \pm 0,1$ & $0,37 \pm 0,5$ & $\mathrm{p}>0,05 ; Z>Z_{0,05}$ \\
\hline Миелопероксидаза, \% & $61,2 \pm 7,2$ & $92,8 \pm 3,3$ & $\mathrm{p}<0,05 ; \mathrm{Z}<\mathrm{Z}_{0,05}$ \\
\hline $\operatorname{IgM,~г/л~}$ & $0,91 \pm 0,3$ & $1,12 \pm 0,5$ & $\mathrm{p}>0,05 ; \mathrm{Z}>\mathrm{Z}_{0,05}$ \\
\hline $\operatorname{IgA}$, г/д & $0,67 \pm 0,2$ & $0,86 \pm 0,4$ & $\mathrm{p}>0,05 ; \mathrm{Z}>\mathrm{Z}_{0,05}$ \\
\hline $\operatorname{IgG}$, г/л & $8,81 \pm 1,2$ & $7,94 \pm 1,1$ & $\mathrm{p}>0,05 ; \mathrm{Z}>\mathrm{Z}_{0,05}$ \\
\hline IgE, MЕ/мЛ & $26,11 \pm 5,4$ & $19,83 \pm 4,6$ & $\mathrm{p}>0,05 ; Z>Z_{0,05}$ \\
\hline $\operatorname{IgG1,~г/л~}$ & $5,1 \pm 2,2$ & $5,7 \pm 3,5$ & $\mathrm{p}>0,05 ; \mathrm{Z}>\mathrm{Z}_{0,05}$ \\
\hline $\operatorname{IgG2,~г/л~}$ & $1,8 \pm 0,9$ & $1,6 \pm 0,7$ & $\mathrm{p}>0,05 ; \mathrm{Z}>\mathrm{Z}_{0,05}$ \\
\hline $\operatorname{IgG3,~г/л~}$ & $0,8 \pm 0,4$ & $0,6 \pm 0,4$ & $\mathrm{p}>0,05 ; Z>Z_{0,05}$ \\
\hline $\mathrm{IgG4,} \mathrm{г/л}$ & $0,3 \pm 0,1$ & $0,2 \pm 0,09$ & $\mathrm{p}>0,05 ; \mathrm{Z}>\mathrm{Z}_{0,05}$ \\
\hline
\end{tabular}


В свете выявленных нами иммунологических данных, представляется очевидным, что, по крайне мере, в части представленных случаев, указанные иммунные нарушения были лишь фрагментами более широкого фенотипа иммунодефицита, ассоциированного с генетическими нарушениями фолатного цикла. Также следует помнить о неклассифицированных аутоиммунных реакциях, включая продукцию аутоантител к антигенам коры головного мозга, о которых сообщали ранее в контексте расстройств аутистического спектра у детей $[8,14]$.

Таблица 2.

Результаты измерения отношения шансов и 95\% доверительного интервала показателей иммунного статуса у пациентов групп наблюдения

\begin{tabular}{|l|l|l|l|l|}
\hline $\begin{array}{c}\text { Дефицит } \\
\text { клетки/фактора }\end{array}$ & N ИГ & N КГ & \multicolumn{1}{|c|}{ OR } & \multicolumn{1}{|c|}{$\mathbf{9 5 \%}$ С I } \\
\hline NK и/или NKT-клетки & 71 & 9 & 28,17 & $7,85-56,82^{*}$ \\
\hline NK+ NKT & 48 & 4 & 12,0 & $3,93-36,29^{*}$ \\
\hline NK-клетки & 58 & 7 & 11,18 & $4,34-28,50^{*}$ \\
\hline NKT-клетки & 62 & 6 & 18.08 & $6,42-50,41^{*}$ \\
\hline CD8+ T-лимфоциты & 18 & 4 & 2,25 & $0,70-7,17$ \\
\hline Миелопероксидаза & 27 & 4 & 3,97 & $1,27-12,42^{*}$ \\
\hline
\end{tabular}

Примечание. ${ }^{*}$ - $\alpha=0,05$.

Поскольку в структуре иммунодефицита у детей с расстройствами спектра аутизма преобладали клеточные нарушения иммунитета, имеющийся инфекционный синдром был представлен преимушественно внутриклеточными патогенами, прежде всего - оппортунистическими вирусами из семейства герпеса. Ранее о такой ассоциации сообщал Binstock T. [1]. Комбинация клеточного иммунодефицитам с расстройствами гуморального иммунитета опосредовала повышенную чувствительность к стрептококку и связанной с этим патогеном форме нейроревматизма в виде PANDAS, а дефицит миелоперокисдазы - склонность к кандидозу (рис. 1). Помимо инфекционных проявлений, иммунодефицит, отмечающийся у детей с расстройствами спектра аутизма, ассоциированными с генетическим 
дефицитом фолатного цикла, приводил к аутоиммунным и аллергическим синдромам.

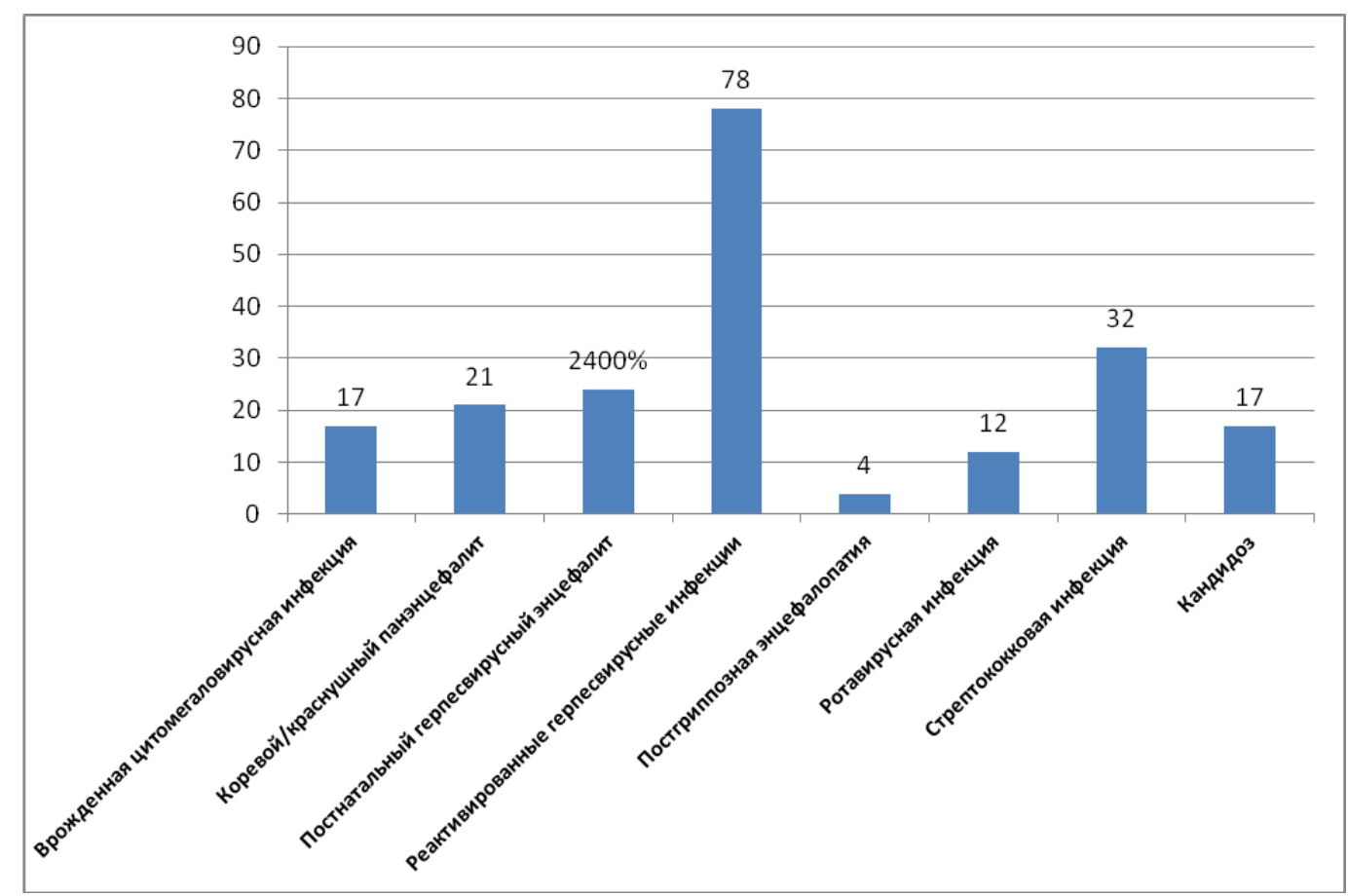

Рис. 1. Структура инфекционного синдрома у пациентов с генетическим дефицитом фолатного цикла $(\mathrm{n}=78)$

Действительно, у детей исследуемой группы, помимо внутриклеточных инфекций, отмечалась повышенная продукция антимозговых антител, преимущественно - против основного белка миелина и нейронспецифической энолазы (около 70\%), a также признаки аутосенсибилизации нейтрофилов (32\%) и $\mathrm{CD} 8+$ цитотоксических Tлимфоцитов (24\% случаев) к антигенам мозга (рис. 2). Связь хронических вирусных инфекций и аутосенсибилизации к мозговым антигенам, например, из-за механизма молекулярной мимикрии, хорошо известна, в частности при рассеяном склерозе. По-видимому, генетический дефицит фолатного цикла способствовал как снижению резистентности к внутриклеточным патогенам, так и индукции аутоиммунных реакций, что указывает на нарушение иммунного статуса у таких пациентов. Тем более, что ранее уже 
неоднократно сообщали о повышенном риске развития рассеянного склероза при генетическом дефиците цикла фолиевой кислоты.

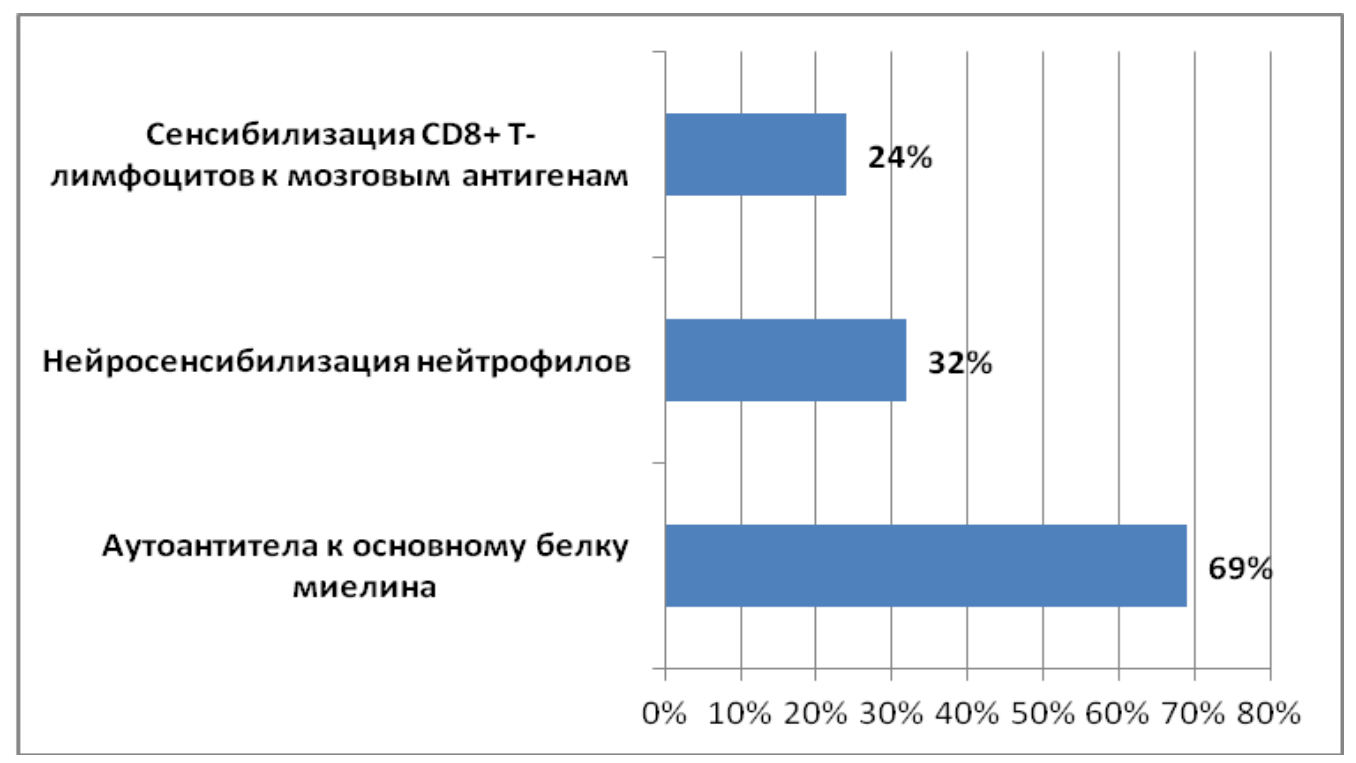

Рис. 2. Структура проявлений антимиелинового аутоиммунитета у детей исследумой группы $(\mathrm{n}=78)$

Этот антимиелиновый аутоиммунитет был не простым свидетелем, а активным участником патологического процесса, поскольку коррелировал с проявлениями лейкоэнцефалопатии. Наряду с оппортунистическими вирусами, антимиелиновые атоиммунные реакции следует рассматривать как причину нарушения развития миелина в полушариях большого мозга, особенно - в перивентрикулярных участках теменных долей, у детей с расстройствами спектра аутизма. Тяжесть лейкоэнцефалопатии широко варьирует и связана как с интенсивностью аутоиммунной реакции, так и с выраженностью психических нарушений. Ниже приведен спектр радиологических проявлений лейкоэнцефалопатии у детей с расстройствами спектра аутизма, ассоциированными с генетическим дефицитом фолатного цикла (рис. 3). 
Рис. 3. Гетерогенность проявлений лейкоэнцефалопатии $\mathrm{y}$ детей $\mathrm{c}$ генетическим нарушением фолатного цикла

(А - незрелость головного мозга и диффузное нарушение миелинизации; Б обширная перивентрикулярная демиелинизация, напоминающая лейкодистрофию; В - выраженная билатеральная демиелинизация в теменных долях перивентрикулярно, дизгенезия мозга, деформация желудочковой системы, $\Gamma$ - ограниченное двустороннее нарушение миелинизации в теменных долях перивентриулярно; собственные наблюдения). 
Кроме того, у детей $\mathrm{c}$ расстройствами спектра аутизма, ассоциированными с генетическим дефицитом фолатного цикла, в 33\% случаев отмечаются признаки антинейронального аутоиммунитета. Чаще всего выявлялась продукция аутоантител к глутаминовой декарбоксилазе нейронов (GADA) - в 61\% случаев, реже - к калиевым каналам нервных клеток (34\% случаев). У некоторых пациентов имела место аутоиммунизация к амфифизину (19\%) и рецепторам к N-метил-D-аспартату (NMDA) (3\%) (рис. 4). Такие антинейрональные аутоантитела известны в контексте учения об аутоиммунных энцефалитах у взрослых и детей, которые проявляются психотическими, эпилептическими, экстрапирамидными и когнитивными расстройствами. Таким образом, наличие антинейрональной аутоиммунизации $\mathrm{y}$ детей $\mathrm{c}$ расстройствами спектра аутизма может объяснить происхождение некоторых клинических проявлений имеющегося психиатрического заболевания.

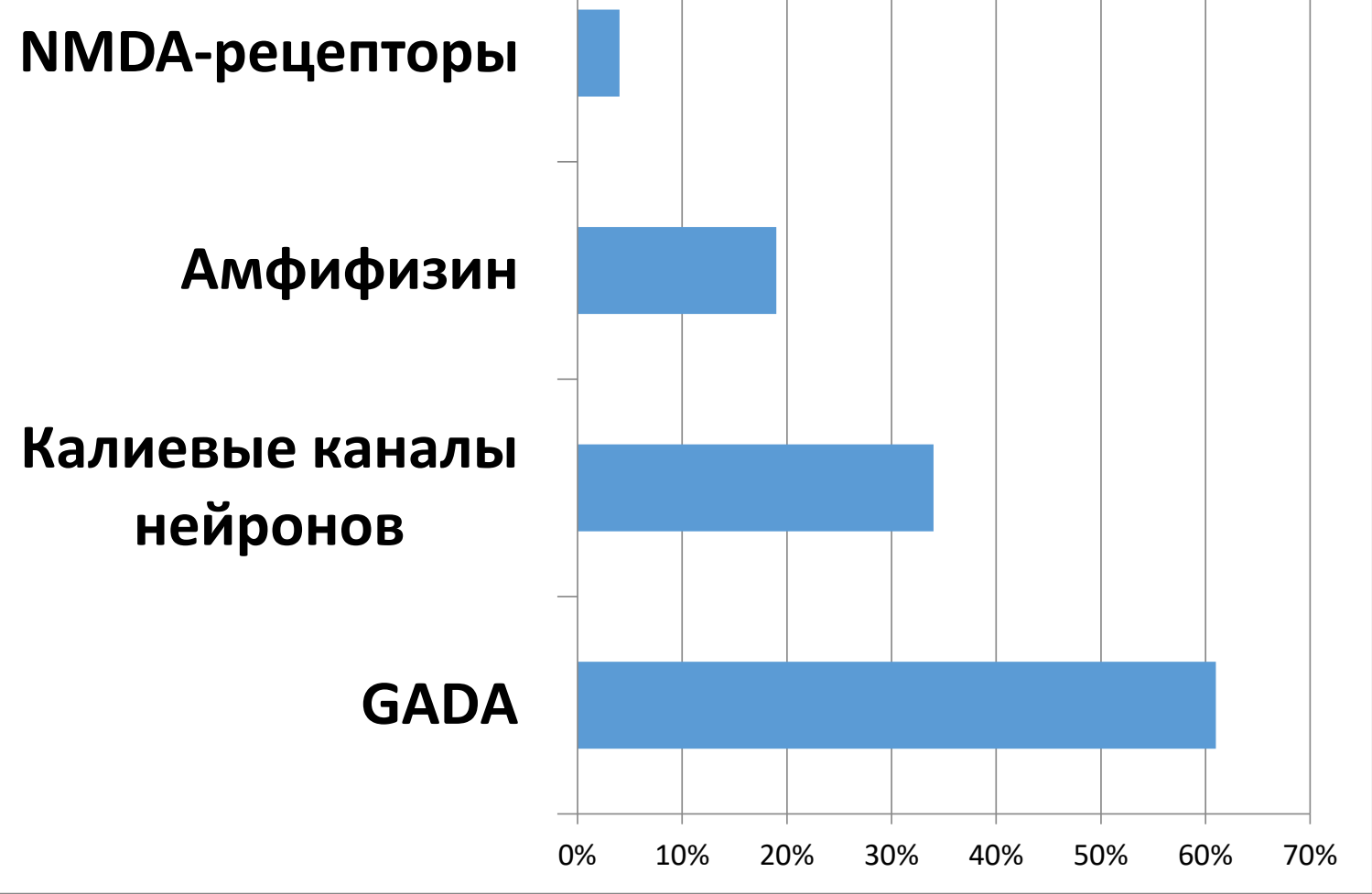

Рис. 4. Структура проявлений антинейронального аутоиммунитета у детей исследуемой группы $(\mathrm{n}=78)$ 
Выводы и перспективы дальнейших исследований. Иммунная дисфункция при расстройствах спектра аутизма имеет вариабельный иммунологический фенотип, однако дефициты NK-, NKT-клеток, CD8+ Tлимфоцитов и миелопероксидазы являются наиболее типичными признаками болезни. Преимущественное вовлечение NK- и NKT-клеток предопределяет избирательное и резкое снижение резистентности к внутриклеточным микроорганизмам, включая оппортунистические вирусы, склонность к индукции аутоиммунных реакций к миелину и нейронам и проявлений гиперчувствительности замедленного типа. Данный первичный иммунодефицит позволяет объяснить ключевые особенности широкого клинико-лабораторного фенотипа болезни и объединить, на первый взгляд, разрозненные синдромы, которые часто последовательно или одновременно развиваются у детей с аутистическим спектром, ассоциированным с генетически детерминированным дефицитом фолатного цикла (психиатрический, эпилептический, кишечный, аллергический, инфекционный, ревматический). Также эта новая форма первичного иммунодефицита может быть объектом эффективных терапевтических вмешательств с мультимодальным воздействием, позволяющих достигнуть прогресса в лечении болезни.

\section{Список использованных источников}

1. Binstock, T. (2001), "Intra-monocyte pathogens delineate autism subgroups" Med. Hypotheses, vol. 56(4), pp. 523-531.

2. DelGiudice-Asch, G., Simon, L., Schmeidler, J. (1999), "Brief report: a pilot open clinical trial of intravenous immunoglobulin in childhood autism" J. Autism Dev. Disord, vol. 29(2), pp. 157-160.

3. Engman, M.L., Sundin, M., Miniscalco, C. (2015), "Prenatal acquired cytomegalovirus infection should be considered in children with autism" Acta Paediatr, vol. 104(8), pp. 792-795. 
4. Ghaziuddin, M., Al-Khouri, I., Ghaziuddin, N. "Autistic symptoms following herpes encephalitis" Eur. Child. Adolesc. Psychiatry, vol. 11(3), pp. $142-146$.

5. Inaoka, M. (2005), "Innate immunity and hypersensitivity syndrome" Toxicology. vol. 209(2), pp. 161-163.

6. Jyonouchi, H., Geng, L., Streck, D.L., Toruner G.A. (2012), "Immunological characterization and transcription profiling of peripheral blood (PB) monocytes in children with autism spectrum disorders (ASD) and specific polysaccharide antibody deficiency (SPAD): case study" J. Neuroinflammation, vol. 9 , pp. 4.

7. Kawikova, I., Grady, B.P., Tobiasova, Z. et al. (2010), "Children with Tourette's syndrome may suffer immunoglobulin A dysgammaglobulinemia: preliminary report” Biol. Psychiatry, vol. 67(7), pp. 679-683.

8. Mora, M., Quintero, L., Cardenas, R. (2009) “Association between HSV-2 infection and serum anti-rat brain antibodies in patients with autism" Invest. Clin., vol. 50(3), pp. 315-326.

9. Plebani, A., Duse, M., Tiberti, S. (1988), "Intravenous gamma-globulin therapy and serum IgG subclass levels in intractable childhood epilepsy" Monogr. Allergy, vol. 23, pp. 204-215.

10. Reinert, P., Moulias, R., Goust, J.M. (1972), “Demonstration of cellular immunity deficiency limited to measles virus in 20 cases of subacute sclerosing leukoencephalitis" Arch. Fr. Pediatr, vol. 29(6), pp. 655-665.

11. Russo, A.J., Krigsman, A., Jepson, B., Wakefield, A. (2009), "Low serum myeloperoxidase in autistic children with gastrointestinal disease" Clinical and Experimental Gastroenterology, vol. 2, pp. 85-94.

12. Santaella, M.L., Varela, Y., Linares, N., Disdier, O.M. (2008), "Prevalence of autism spectrum disorders in relatives of patients with selective immunoglobulin A deficiency" P. R. Health. Sci J, vol. 27(3), pp. 204-208.

13. Schleinitz, N., Vély, F., Harlé, J.N., Vivier, E. (2010), "Natural killer cells in human autoimmune diseases" Immunology, vol. 131(4), pp. 451-458. 
14. Singh, V.K., Lin, S.X., Yang, V.C. (1998), "Serological association of measles virus and human herpesvirus- 6 with brain autoantibodies in autism" Clin. Immunol. Immunopathol, vol. 89(1), pp. 105-108.

\section{References}

1. Binstock, T. (2001), "Intra-monocyte pathogens delineate autism subgroups", Med. Hypotheses, vol. 56(4), pp. 523-531.

2. DelGiudice-Asch, G. Simon, L. and Schmeidler, J. (1999), "Brief report: a pilot open clinical trial of intravenous immunoglobulin in childhood autism", J. Autism Dev. Disord, vol. 29(2), pp. 157-160.

3. Engman, M.L. Sundin, M. and Miniscalco, C. (2015), "Prenatal acquired cytomegalovirus infection should be considered in children with autism", Acta Paediatr, vol. 104(8), pp. 792-795.

4. Ghaziuddin, M. Al-Khouri, I. and Ghaziuddin, N. "Autistic symptoms following herpes encephalitis", Eur. Child. Adolesc. Psychiatry, vol. 11(3), pp. $142-146$.

5. Inaoka, M. (2005), "Innate immunity and hypersensitivity syndrome", Toxicology, vol. 209(2), pp. 161-163.

6. Jyonouchi, H. Geng, L. Streck, D.L. and Toruner, G.A. (2012), "Immunological characterization and transcription profiling of peripheral blood (PB) monocytes in children with autism spectrum disorders (ASD) and specific polysaccharide antibody deficiency (SPAD): case study", J. Neuroinflammation, vol. 9 , pp. 4.

7. Kawikova, I. Grady, B.P. and Tobiasova, Z. et al. (2010), "Children with Tourette's syndrome may suffer immunoglobulin A dysgammaglobulinemia: preliminary report", Biol. Psychiatry, vol. 67(7), pp. 679-683.

8. Mora, M. Quintero, L. and Cardenas, R. (2009) "Association between HSV-2 infection and serum anti-rat brain antibodies in patients with autism", Invest. Clin., vol. 50(3), pp. 315-326. 
9. Plebani, A. Duse, M. and Tiberti, S. (1988), "Intravenous gamma-globulin therapy and serum IgG subclass levels in intractable childhood epilepsy", Monogr. Allergy, vol. 23, pp. 204-215.

10. Reinert, P. Moulias, R. and Goust, J.M. (1972), "Demonstration of cellular immunity deficiency limited to measles virus in 20 cases of subacute sclerosing leukoencephalitis", Arch. Fr. Pediatr, vol. 29(6), pp. 655-665.

11. Russo, A.J. Krigsman, A. Jepson, B. and Wakefield, A. (2009), "Low serum myeloperoxidase in autistic children with gastrointestinal disease", Clinical and Experimental Gastroenterology, vol. 2, pp. 85-94.

12. Santaella, M.L. Varela, Y. Linares, N. and Disdier, O.M. (2008), "Prevalence of autism spectrum disorders in relatives of patients with selective immunoglobulin A deficiency", P. R. Health. Sci J, vol. 27(3), pp. 204-208.

13. Schleinitz, N. Vély, F. Harlé, J.N. and Vivier, E. (2010), "Natural killer cells in human autoimmune diseases", Immunology, vol. 131(4), pp. 451-458.

14. Singh, V.K. Lin, S.X. and Yang, V.C. (1998), "Serological association of measles virus and human herpesvirus- 6 with brain autoantibodies in autism", Clin. Immunol. Immunopathol, vol. 89(1), pp. 105-108. 